\title{
Myth, Ritual, and the Early Development of Shiite Identity $^{*}$
}

\author{
Torsten Hylén \\ Dalarna University, Falun, Sweden \\ thy@du.se
}

\begin{abstract}
The developing myth about the events at Karbala, as well as the image of al-Husayn b. 'Alī and the cult connected with him, were important factors in the shaping of early Shiite identity. In this article, I argue that some of the earliest traces of this process are found in the account of the Tawwābūn, or Penitents, events which took place in the years immediately following the death of al-Husayn at Karbala in 6o/68o. Important elements of this story originate at least as early as the late first/early eighth century. In the story we see the image of al-Husayn in process of transformation from that of someone merely human to someone ascribed traits that transcend the human. In the same course of events, the story of his death at Karbala is in process of being elevated from a tragic story to a myth with its associated rituals.
\end{abstract}

\section{Keywords}

Shiism - Tawwābūn - Ḥusayn b. 'Alī - Karbala - myth - ritual

* This article is one of the fruits of the research project "Revenge or Martyrdom! The Story of the Penitents as a Link to the Early Development of Shi ism," funded by the Swedish Research Council (reg. no. 421-2011-1806). It is a developed version of a paper presented at the conference "The Mythic Dimension of Islam: Examining the Sources through the Lens of Myth". I am grateful to comments and feedback from the participants. I also want to thank my colleague at Dalarna University, Dr Therese Rodin, for reading and commenting on an earlier version of this piece.

(C) TORSTEN HYLÉN, 2018 | DOI: 10.1163/2212943X-00603004

This is an open access article distributed under the terms of the prevailing CC-BY-NC-ND license at the time of publication. 


\section{Introduction}

The developing myth about the events at Karbala, as well as the image of alHusayn b. 'Alī and the cult connected with him, were important factors in the shaping of early Shiite identity. In this article, I will argue that some of the earliest traces of this process are to be found in the account of the movement of the Tawwābūn, or Penitents, events which took place in the years immediately following the death of al-Husayn at Karbala in 6o/68o. I will try to demonstrate that important elements of this story originate at least as early as the late first/early eighth century. In the story we see the image of al-Husayn in process of transformation from that of someone merely human (if with special status as the grandson of the Prophet Muhammad) to someone ascribed traits that transcend the human. In the same course of events, the story of his death at Karbala is in process of being elevated from a tragic account of a battle to a myth with its associated rituals.

I have previously published a study that addressed the dating of a section of the story of the Tawwābūn. ${ }^{1}$ Whereas in that earlier study I concentrated on the treatment of the visit of the Tawwābūn to the grave of al-Husayn, in the present article I direct my main attention to four programmatic texts associated with the beginning of the story - to three speeches and a letter that express the ideas and attitudes of the group. The four programmatic texts will be compared with the section on the visit to the grave. Although both sets of texts will be analysed from a theoretical framework differing slightly from the previous study, several accounts and arguments will have to be repeated here.

\section{On Myth as an Analytical Category}

In the present context, I define "myth" as a narrative that is foundational to the world view and identity of a group of people. ${ }^{2}$ Thus myth, as I use the term, has nothing to do with whether a story is historically "factual" or "fictional," "true" or "false". It is a story with a specific function as foundational. Furthermore, when a story functions as a myth, it always does so to someone. Thus as I use the concept, a story is not a myth in itself, but only in relation to a group of persons.

1 Hylén, "Date".

2 For a discussion leading up to this definition, see Hylén, "Ḥusayn, the Mediator," pp. 20-31. 
I agree with the historian of religion Russel McCutcheon and others that myth is normally ideological in the sense that it carries with it political implications. ${ }^{3}$ McCutcheon prefers to write of "mythmaking" as an active and very natural process, rather than about "myth" as a passive label stuck onto certain types of stories. ${ }^{4}$ Myth-making, to him, is "the ongoing process of constructing, authorising and reconstructing social identities or social formations." ${ }^{5}$ Thus myth, according to McCutcheon, has a crucial role in the formation of social groups. He quotes the New Testament scholar Burton L. Mack, who states that "[s]ocial formation and mythmaking are group activities that go together, each stimulating the other in a kind of dynamic feedback system ... Social formation and mythmaking fit together like hand and glove." ${ }^{\text {In }}$ the present context, I will reserve the term "myth" for the narrative expressing or proceeding from mythmaking as described above. The process of myth-making is very clear among early Shiites in general and the Tawwābūn in particular. ${ }^{7}$ In fact, in the account of the Tawwābūn, we see no explicit myth, only a process of myth-making; the Karbala story is not related, only implied, but we can see how the event at Karbala is imbued with values that are instrumental in the creation of a story that is foundational.

A problem with some discussions of myth is that they do not take account of ritual; this is also true of McCutcheon's text referred to here. Many scholars have demonstrated the importance of rituals in the creation and sustaining of group identities. ${ }^{8}$ In particular the anthropologist Paul Connerton discusses the significance of bodily practices, among which rituals are to be counted,

3 McCutcheon, "Myth," pp. 199-207. For a similar argument, see Lincoln, Theorizing Myth, p. 147.

4 McCutcheon, "Myth," pp. 199-201. I find the idea of myth-making as a process appealing, with the reservation that it is normally not a consciously active process.

5 Ibid., p. 202.

6 Ibid., p. 203, quoting Mack, Who Wrote the New Testament, p. 11.

7 For this myth-making in relation to community formation in early Shiism (although none of the studies mentioned here use this concept), see e.g. Amir-Moezzi, "Dìn 'Alī"; Dakake, Charismatic Community; Kohlberg, "From Imāmiyya to Ithnā-'Ashariyya"; idem, "Imām and Community in the Pre-Ghayba Period".

8 To mention just a few that from very different theoretical perspectives and with varying data demonstrate this, see e.g. Durkheim, Les Formes élémentaires; Turner, Ritual Process; Asad, Genealogies of Religion; Penn, Kissing Christians; Houseman, "Relationality". Some examples from scholars of early Islam will suffice: Josef van Ess points to the importance of the șalätor rather where and behind whom it was performed - for the identity formation of groups within emerging Islam (Theologie und Gesellschaft, vol. IV, pp. 680-681); Leor Halevi shows how mortuary rituals had the same function both between Muslim groups and in relation to 
as means for internalisation and for the uninterrupted sustaining of values of a society. As behaviours are automatised, the body (not just the intellect) "remembers" them. Furthermore, he argues, behaviour is conservative, and far less prone to change than the ideas and thoughts that give behaviour its "meaning" in an intellectual sense. Thus bodily practices are important for what he calls "social memory". 9 The interpretation of ritual, on the other hand-that is, the process of filling rituals, so to say, with an intellectual content-depends on myths which make up what Connerton calls "a reservoir of meanings". He says: "The mythic material contains a range of potential meanings significantly in excess of their use and function in any particular arrangement, any singular structure."10 Hence rituals are not in themselves bearers of "meaning" in an intellectual sense. They require filling with meaning. Several scholars of ritual argue this, including Caroline Humphrey and James Laidlaw, who write of ritual as "apprehensible" in that "they are, as it were, waiting for, and apt for, the achievement of self-interpretation."11 Thus while rituals normally change very slowly, they are constantly re-interpreted as the historical contexts change.

So I view myth and ritual as closely connected and as mutually reinforcing. ${ }^{12}$ To put it bluntly, rituals internalise and habitualise values and precepts expressed in myths; myths interpret and give meaning to rituals. ${ }^{13}$ An important indication that a story functions as foundational to the world view and identity of a group (or, in other words, is what I define as a myth) is that it is connected with a ritual. ${ }^{14}$ Thus myth and ritual must be seen together as impor-

non-Muslims (Muhammad's Grave, pp. 1-5, 234-240, and passim); for the significance of ritual for the emergence of Shiism see Haider, Origins, pp. 231-248; Aslan, "From Body to Shrine".

9 Connerton, How Societies Remember, pp. 3-5. For an interesting application of Connerton's theory, see Gottschalk, Beyond Hindu and Muslim.

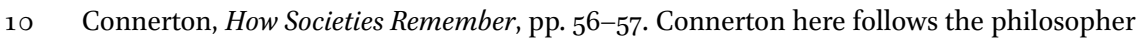
Paul Ricoeur.

11 Humphrey and Laidlaw, Archetypal Actions, pp. 133-166, quote from p. 16o. See also Bell, Ritual, pp. 210-223. Humphrey and Laidlaw, as well as Bell work with theoretical frameworks that differ from that of Connerton.

12 In this I agree with the Israeli scholar Ithamar Gruenwald. However, I would not, at present, go as far as he and define myth as a story that is connected to a ritual (see his Rituals, pp. 96-99).

13 Connerton (How Societies Remember, pp. 72-79) uses the terms incorporating and inscribing practices when referring to these two functions. He does not talk exclusively of myth and ritual, though, but of many kinds of practices and the values and meanings ascribed to them.

14 Although I think that there are stories that are not connected to rituals but still have this 
tant factors in the creation of a group identity. I will argue that in the story of the Tawwābūn, embryos of myth and ritual can be seen emerging as inseparable elements in the process of the crystallisation of a Shiite identity.

\section{The Story of the Tawwābūn: Outline and Authorship ${ }^{15}$}

The background to the account of the Tawwābūn is the killing of al-Husayn b. 'Alī at Karbala in $61 / 680 .{ }^{16}$ We are told that soon after al-Husayn's death, some of the men who had invited him to come to Kufa to lead them in an insurrection against the governor there but then failed to support him felt deep regret for their failure to come to the help of the Prophet's grandson. They gathered and chose Sulaymān b. Șurad as their leader, then discussed how they could best make atonement (Ar. tawba, hence the name of the group, tawwābün) for their crime. They decided they would take to arms and go against the Umayyad army - to kill those who had killed al-Husayn or to be killed themselves in the attempt to avenge him. The Tawwābūn were well aware that this action would in all probability lead to their own deaths, but they regarded it as an act of martyrdom in the cause of loyalty to the Prophet and his descendants, and believed that it would cleanse them from their offence. A few years later, in 65/684, they set out. On their way to the battlefield they stopped at al-Husayn's tomb at Karbala, dedicating themselves to prayer for al-Husayn's soul and remorseful weeping over their own sin. As they moved on, they eventually met the Umayyads at 'Ayn al-Warda in northern Iraq, and were defeated. Some of the few survivors felt great shame not to have been killed in the campaign. ${ }^{17}$

As far as I have been able to detect, the only independent account of the Tawwābūn available to us is that written down by Lūt b. Yahyā al-Azdī, bet-

function, I would say that most stories that are connected with rituals are myths in the sense described above.

15 This entire section draws on and quotes from Hylén, "Date". That study also includes an overview of earlier studies on the story of the Tawwābūn.

16 An extensive account of this event is found in al-Ṭabarī, Tärīh, ser. II, pp. 216-39o. For summaries in translation, see e.g. Wellhausen, Oppositionsparteien, pp. 61-67; Calmard, "Culte," pp. 39-56; Veccia Vaglieri, "Ḥusayn b. 'Alī b. Țālib," $E I^{2}$, vol. 3, pp. 6o7-615; Jafri, Origins, pp. 174-221; Hylén, "Husayn, the Mediator," pp. 205-217.

17 The full text is given in al-Ṭabarī, Tärīh, ser. II, pp. 497-513, 538-578. For more comprehensive summaries in translation, see Wellhausen, Oppositionsparteien, pp. 71-74; Calmard, "Culte," pp. 66-69; Jafri, Origins, pp. 222-234; Halm, Shi'a Islam, pp. 16-20; Denny, "Tawwābūn," $E I^{2}$, vol. 10, p. 398; and Dakake, Charismatic Community, pp. 90-95. 
ter known as Abū Mihnaf (d. 157/774). All other versions are, to my knowledge, dependent on his "book" Kitāb Sulaymān b. Șurad wa-Ayn al-Warda ${ }^{18}$ Abū Mihnaf's original text is lost to us, but seems that it is reproduced in total by Hišām b. al-Kalbī (d. 204/819), and that Ibn al-Kalbī's version in its turn is transmitted by al-Tabarī (d. 310/923). Other Muslim historians, such as Ibn A'tam al-Kūfī, al-Balādurī and al-Mas'ū ū have also given versions of the story. ${ }^{19}$ Like that of alȚabarī, their accounts are based on Abū Mihnaf, but they show traces of heavy editing and are usually abbreviated. In the present study, only al-Ṭabarì's rendering of Abū Mihnaf's text will be consulted. In contrast to the narration of the tragedy of Karbala (which al-Ṭabarī also relates with Abū Mihnaf as his main source), I find relatively few obvious traces of editing from al-Ṭabarîs side. ${ }^{20}$ Although this cannot be stated with certainty because we have only his version of the full text, there are not that many gaps, dents and other irregularities in the text. Of course, Ibn al-Kalbī might have made some editorial changes, but, again, without other versions to compare with, this is difficult to confirm. ${ }^{21}$ There are indeed traces of editing, mainly in the form of later material added to an earlier layer, but most of these are probably done before Abū Mihnaf. ${ }^{22}$ In my

18 Ibn al-Nadīm, Fihrist, vol. 1, p. 93. I have put the word "book" within quotation marks in order to show that by this I do not mean a published book in the modern sense. For a discussion of the question of oral and written material, see Schoeler, The Oral and the Written, pp. $28-44$.

19 Ibn A'tam al-Kūfi, Futūh, vol. 6, pp. 47-53, 58-87. The date of Ibn A'tam's death is contested: Conrad places it at the beginning of the third/ninth century (Conrad, "Ibn A'tham," pp. 9o96), whereas Lindstedt in a couple of recent publications forcefully argues for the more traditional date about a hundred years later (see Lindstedt, "Kitāb al-Dawla," pp. 118-123; "Sources"); al-Balādِurī, Ansāb, pp. 204-213; al-Mas'ūdī, Murūğ, vol. 5, pp. 213-221. There are, however, some indications that versions of this story may have existed that go back to others than Abū Mihnaf. Thus both al-Balādurīi (Ansāb, p. 204) and al-Mas'ūdī (Murūğ, vol. 5, p. 219) refer to "Abū Mihnaf and others" (italics added) as authorities for the story or part of it. Whether "the others" stand for authors dependent on Abū Mihnaf or not, we cannot know.

20 For al-Ṭabarìs editing of the Karbala story, see Hylén, "Husayn, the Mediator," pp. 115-116, 228-231.

21 Al-Balādurīa also refers to Abū Mihnnaf via Ibn al-Kalbī (Ansāb, p. 204), but since al-Balādurūī himself has abbreviated and edited the text, it is impossible to compare it with al-Tabarīs version except on the overall structure or with details in the text. It is quite clear that Ibn A'țam and al-Mas'ūdī have also used Abū Mihnnaf's text as a basis for their own recension, but again, these versions are so strongly edited that it is impossible to make detailed comparisons with al-Ṭabarīs version.

22 Some of these will be discussed below. For an example of a section most probably inserted after Abū Miḩnaf, see Hylén, "Date". 
opinion, the reason for the absence of later editing here is the fact that the story of the Tawwābūn was less politically or theologically inflammable than some other accounts from the early history of Islam such as the killing of 'Utmān, the battle of Șiffin, the battle of the Camel, or the tragedy of the killing of alHusayn at Karbala. In other words, the episode of the Tawwābūn and the story that developed about them were just not important enough for later historians to precipitate a lot of editing of the account to make it fit their views of history and ideology. ${ }^{23}$ For this reason, I presume that al-Tabarīs version very closely follows or even reproduces Abū Mihnaf's work in the main.

It is the first half of the story that is most interesting for the study of early Shiism. This is where the sin of the betrayal of al-Husayn is deliberated on and discussed. By contrast, after the visit to the grave in the middle of the account, the story turns into a common battle description with many of the traditional topoi of such accounts. ${ }^{24}$ Hence in the present study the second half of the story will hardly be touched upon.

Several scholars claim or presuppose that the story is much older than Abū Mihnaf, without really arguing for this. ${ }^{25}$ As I contended in my previous article, I hold it likely that substantial parts of the story go back at least to the end of the first/beginning of the eighth century. (I will summarise the arguments below.) Provided the story is that early, it gives us a unique insight into some of the ideas and rituals of emerging Shiism. Two sections from the account of the Tawwābūn are particularly interesting in this regard, as the ideational elements are very obvious in them: four programmatic texts at the beginning of the story, and the passage about the visit to al-Husayn's grave in the middle. ${ }^{26}$ In the next two sections I will analyse each of these.

23 The later religious significance of this movement for the Shiites is of course another matter, but that would not have occasioned heavy editing of the material.

24 For such topoi (e.g. how the armies are arranged and who are appointed commanders of the different units, the succession of command, messages of victory sent to the caliph, etc.) see Noth and Conrad, Early Arabic Historical Tradition, pp. 111-129.

$25 \operatorname{Halm}$ (Shi'a Islam, p. 18) calls it an old text. Hawting also intimates this ("Tawwābūn," p. 18o, see my discussion below). See Hylén, "Date" for a more extended discussion about this matter.

26 It is interesting to note that, although al-Hiusayn and his death at Karbala are almost omnipresent in the first half of the story, after the visit to the grave his name is not mentioned once, and the relatively few references to him, to his supporters killed at Karbala and to the family of the Prophet are made only in passing (al-Ṭabarī, Tārīh, ser. II, pp. 556, $\left.55^{8}, 571\right)$. 


\section{Four Programmatic Texts}

At the beginning of the story of the Tawwābūn there are four texts which can be regarded as programmatic of the ideas of the group: three speeches, and one letter. The first speech is ascribed to one of the leaders of the Tawwābūn, al-Musayyab b. Nağaba, the second and the letter to its main leader, Sulaymān b. Șurad, and the final speech to the propagandist 'Ubayd Allāh b. 'Abd Allāh al-Murrī.

\section{The Texts}

In the following, I have quoted what I regard as the most important parts of the four texts. Due to restrictions of space, I have summarised the sections that I have not quoted verbatim (mainly the introductions and/or the final parts). I have followed Gerald Hawting's translation in most cases; although in a few cases I have made minor changes. ${ }^{27}$ To facilitate reference, each text has been assigned a roman number (I-IV), and the texts have been divided into sections. When referring to a text in the following analysis, I will give the roman number of the text followed by the number of the section in that text (e.g. I.3).

The first two speeches, ascribed to al-Musayyab b. Nağaba and Sulaymān b. Şurad respectively, are found in the same habar. Its isnād is the following: ${ }^{28}$ Hišām b. Muḥammad [al-Kalbī]_Abū Mihunaf-Yūsuf b. Yazīd_c'Abd Allāh b. 'Awf b. al-Ahmar al-Azdī. Thus there are two links in the chain of transmission between Abū Mihnaf and the occasion described. All we know of Yūsuf b. Yazīd is that he was an authority frequently used by Abū Mihnaf; ${ }^{29}$ 'Abdallāh b. 'Awf is unknown to us. The habar, which is quite long, ${ }^{30}$ relates how the group met first

27 Tabarī, History. I will normally refer only to the Leiden edition of al-Tabarī's Tärīh, however. Hawting's translation gives the pagination of the Leiden edition in the margin, and it should be easy for any reader to consult the English text even though it is not referred to directly. I have normally not included transcriptions of Arabic terms that Hawting has inserted within square brackets. On the other hand, I have inserted transcriptions of words and phrases within brackets where this has been important for the analysis that follows.

28 The Arabic term habar (pl. ahbār) denotes "a self-contained narrative unit which depicts an incident or a limited sequence of occurrences or conveys sayings" (Leder, "The Literary Use of the Khabar". The quote is from p. 279). Typically, each habar is preceded by a chain of authorities (isnād, pl. asānìd) that have transmitted it. Early Arabic historiography to a great extent consists of compilations of such ahbār.

29 Sezgin, Abū Mihnaf, p. 226.

3о Al-Ṭabarī, Tārīh, ser. II, pp. 497-501. 
in the house of Sulaymān b. Surad, full of guilt and repentance over their failure to support al-Hiusayn at Karbala. There, al-Musayyab and Sulaymān deliver their speeches.

\section{Text I (Speech by al-Musayyab b. Nağaba)}

Al-Musayyab begins his talk by referring to the advanced age of all those assembled, and the need to repent before life here on earth ends. He continues:

1) We were enamoured of self-justification and praising our party [šča $a$ until God put our best men to the test and found us sham on two of the battlefields of the son of our Prophet's daughter.

2) Before that, we had received his letters and his messengers had come to us offering forgiveness, asking us to help him again in public and in private.

3) But we withheld ourselves from him until he was killed so near to us. We did not help him with our hands, argue on his behalf with our tongues, strengthen him with our wealth or seek help for him from our clans.

4) What will be our excuse for our Lord and at the meeting with our Prophet when his descendant, his loved one, his offspring and his issue has been slain among us? No, by God, there is no excuse unless you kill his murderer and those who assisted him or unless you are killed while seeking that. Perhaps our Lord will be satisfied with us in that, for I have no security against His punishment after meeting Him.

Al-Musayyab finishes the speech by urging the assembled to elect a commander who can lead them in this act of vengeance. ${ }^{31}$

The group agrees on electing Sulaymān b. Șurad as their leader, and he delivers his speech:

Text II (Speech by Sulaymān b. Șurad)

Having praised God and confessed his faith in God and the Prophethood of Muhammad, Sulaymān continues by lamenting that the times have deteriorated. Then he goes on:

1) What good is it for the most virtuous of this party [šsica] that we were yearning for the family of our Prophet [ $\bar{a} l$ nabiyyina $\bar{a}]$ to come, offering them help and urging them to come,

2) but when they came we were weak and feeble and spineless, we delayed and waited to see what would happen, until the descendant of our Proph-

Al-Ṭabarī, Tärīh̆, ser. II, pp. 498-499. 
et, his offspring and his progeny, flesh of his flesh and blood of his blood, was killed in our very midst? He called for help but received none, he asked for justice but was not given any.

3) The impious ones made him a target for arrows and a butt for spears until they had broken him, assaulted him and stripped him.

4) Rise up indeed, for your Lord has been angered. Do not go back to your wives and children until God has been satisfied! By God, I do not think He will be satisfied unless you fight against those who killed him or perish. Do not fear death! By God, no man ever feared it without debasing himself.

5) Be like those Israelites when their prophet said to them, "You have done evil to yourselves by your adoption of the Calf. Turn in repentance $[t \bar{u} b \bar{u}]$ to your Creator and kill yourselves. That will be best for you with your Creator." ${ }^{\prime 2}$ And do what the people did. They fell on their knees and stretched out their necks and accepted the judgment, until they understood that nothing would save them from the magnitude of their offence except patient acceptance and slaughter.

6) How will it be with you, if you are summoned to something similar? Make sharp the swords, assemble the lances, "and get ready against them what strength you can. Prepare for war"33 so you can be assembled when you are summoned to fight. ${ }^{34}$

Later, Sulaymān writes a letter to the Shiites of al-Madāin and Basra. The letter is reported to Abū Mihnaf by a certain al-Ḥuṣayn b. Yazīd b. 'Abdallāh b. Sa'd b. Nufayl. Nothing is known of this man except that his grandfather, 'Abd Allāh b. Sa'd b. Nufayl, was one of the five leaders of the Tawwābūn and was killed at 'Ayn al-Warda as the deputy of Sulaymān b. Surad. ${ }^{35} \mathrm{He}$ is the only authority in the isnād of the letter, and he says that he first read it when Sulaymān (b. 'Abd al-Azīz) was caliph, i.e. 96-99/715-717.

\section{Text III (Letter from Sulaymān b. Șurad)}

After the traditional greetings, Sulaymān regrets the present state of the world, and states that "the best servants of God" have decided to leave it for the glories of the coming world. He continues:

\footnotetext{
32 Qửān 2:54.

33 Qurān 8:6o. Hawting has not indicated this passage as Qurānic.

34 Al-Ṭabarī, Tärīh, ser. II, pp. 500-501.

35 Al-Ṭabarī, Tārīh, ser. II, p. 497, 556, 562. See also Sezgin, Abū Mihnaf, pp. 207-2o8.
} 
1) The friends of God among your brethren and the party [ [š̃a] of your Prophet's family [äl nabiyyikum] have reflected upon the way they were put to the test in the matter of the son of their Prophet's daughter. ${ }^{36}$

2) He responded when he was invited but received no answer when he called, wanted to go back but was detained, asked for safe-conduct but was denied it.

3) He refrained from attacking the people although they did not refrain from him, but attacked and killed him, then plundered and stripped him wrongfully and in enmity, heedless and ignorant of God. What they did offended God and they will not return to Him. "Those who commit evil will know the reversal which they will endure." ${ }^{37}$

4) When your brethren considered and thought about the end to which they were coming, they saw they had sinned greatly in betraying the pure and good one, in delivering him up and refraining from aiding and helping him.

5) They saw there was no release for them and no repentance [tawba] apart from killing his murderers or killing themselves so that their spirits would be consumed in it. Your brethren have thought seriously, and you should too and prepare.

In the second half of the letter, Sulaymān sets a place and a time for the people of al-Madāin and Basra to meet the Kufans. He then encourages the readers to join them in the struggle and to be prepared to meet death in repentance of their sins. ${ }^{38}$

While it is impossible to conclude that even parts of this letter were actually written by Sulaymān, certain features in the second half of the rather long letter lead me to suspect that this part is a later addition to an earlier original. I will return to this question shortly.

The final speech is related by al-Husayn b. Yazìd (that is, the same authority as in the previous text), on the authority of "a man of Muzayna". Of course we cannot know who the latter was or what his credentials were as a source. ${ }^{39}$ The speech is supposed to be a call to the Kufans to join the Tawwābūn, given by the propagandist $(a l-d \bar{a} c)$ ' Ubayd Allāh b. 'Abd Allāh al-Murrī, who is otherwise unknown to us.

$36 \quad$... ibn bint nabiyyihum. Hawting has translated this "their Prophet's grandson".

37 Qurān 26:227.

38 Al-Ṭabarī, Tārīh, ser. II, pp. 502-504.

39 Al-Ṭabarī, Tārīh, ser. II, p. $5 \circ 7$. 
Text IV (Speech by 'Ubaydallāh b. 'Abd Allāh al-Murrī)

'Ubayd Allāh begins his speech by recapitulating the position of the Prophet Muhammad as God's elected, who has guided the community from destruction to God. He then continues:

1) Has God created among the first and the last anyone with a greater right to authority over this community than its Prophet? And have the descendants of any one of the prophets and messengers or anyone else a greater right to rule over this community than those of its Messenger? No, by God, there has not been and there will not be.

2) You belong to God. Have you not seen and have you not heard what evil was done to the son of your Prophet's daughter? Did you not regard how the people violated his sanctity, considered as weakness his solitariness, splattered him with blood, and pulled him down to the ground? In it they did not respect their Lord or al-Husayn's kinship with the Prophet. They made him a target for arrows and left him a slaughter for the hyenas.

3) Blessed are the eyes of him who has seen the like of him, and blessed is Husayn the son of 'Alī. What a man was he they betrayed! He was true and patient, trustworthy, helpful and resolute; he was the son of the first of the Muslims in Islam and the son of the daughter of the Messenger of the Lord of the Worlds.

4) His defenders were few while his foes flocked around him, and his enemy killed him while his friend betrayed him. Woe to the killer and shame on the traitor!

5) God will accept no plea from his killer and no excuse from his betrayer unless he sincerely turns to God in repentance [tawba], struggles against the murderers, and opposes the unrighteous. Perhaps on those conditions God will accept the repentance $[t a w b a]$ and disregard the offence.

6) We call you to the Book of God, the Sunna of His Prophet, the seeking of vengeance for the blood of his family [ahl baytihi], and the struggle against the violators of God's law and renegades. If we are killed, that which God has prepared for us with Him is better for the godfearing; if we are victorious, then we will restore this authority to the family of our Prophet [ahl bayt nabiyyinā $] !^{10}$ 


\section{Analysis}

The first three texts, excepting the second half of Text III (the letter from Sulaymān, which will be discussed below), are similar in structure as well as content. The following elements are included in all three texts, in roughly the same order:

(a) They begin by talking about leaving the present life. This leads to the considerations expressed in (f) and (g) below.

(b) The speaker speaks of his group as the šša, the "party" (I.1; II.1; III.1).

(c) Al-Husayn is spoken of as the offspring or grandson of the Prophet (I.1, 4; II.2; III.1).

(d) Al-Husayn had been invited by the Shiites and/or asked for their support (I.2; II.1; III.2).

(e) But the Shiites did not help or support him, and he was killed (I.3; II.2, 3; III.2).

(f) God has been offended; the Shiites have committed a sin (I.4 (implied); II.4; III.4).

(g) The only way to show true repentance is to seek revenge for al-Husayn's death or to die in the attempt (I.4; II.4-6; III.5).

In my view, these similarities indicate that the first three speeches may go back to an earlier and probably oral tradition. Although we can hardly regard them as "replays of tape recordings"41 of what al-Musayyab and Sulaymān said and wrote, they could well be a rendering of an early tradition about the Tawwābūn which relates the main ideas of the group.

As I have indicated above, I doubt that the second half of Sulaymān's letter (Text III), which I have not rendered in full here, is part of the original text. There are three reasons for this.

Firstly, the first half of the letter is self-contained. After section III.5, a date and a place for the mustering of the forces are set. (Whether these sentences belong to the original first half or the attached second part is unclear. See the discussion below.) What comes after is a general call to repentance through ğiha $\bar{d}$, which is quite redundant in relation to the first half of the letter.

Secondly, the content of the second half of the letter differs from that of the three documents outlined above. Here, the motif of revenge for the death of al-Husayn is totally absent. In fact he is never mentioned, and the only time

41 This expression is taken from John P. Meier, who often uses it in a similar way in his books about the historical Jesus; see e.g. Meier, A Marginal Jew, pp. 42, $5^{21 .}$ 
the family of the Prophet is brought up is in a general exhortation to fight against their enemies. Those addressed in the letter are several times exhorted to repent, but the nature of the sin is not discussed. In fact, this is the section in the story where derivates of the root $t-w-b$ ("turning" or "repentance") are most frequent; four out of a total eighteen or so occurrences ${ }^{42}$ in the story are found in these lines. The author of this part refers to those previously killed "as martyrs" and as exemplars of how one should behave when tested by God (a later narrator has added a gloss that this refers to Ḥuğr b. 'Adī and his followers). Already in Text II.4 a similar pattern for imitation is given. There, the story of the Children of Israel and their acceptance of judgment after the incident of the Golden Calf is alluded to. However, rather than martyrdom, the case of the Israelites is described as humble acceptance of God's punishment for the sin they had committed. Furthermore, the interpretation offered of the Golden Calf incident in II.4 is very unusual, and also quite unorthodox. ${ }^{43}$ This is implied in the saying ascribed to Haalid b. Sa'd that directly follows Text II, where he says that killing oneself "is something which was ordered to a people who were before us while we have been prohibited from it."44 In my view, for someone to have inserted such a strange interpretation of the Golden Calf incident at a later stage is unlikely, and I therefore regard Section II.4 as original. In contrast, I am inclined to think that someone has attached the second half of Text III in order to emphasise the motif of repentance. This editor has been following the pattern of Text II.4, but, unwilling to take such an unorthodox interpretation of the Quranic text, he has taken a more acceptable example as a model to be imitated.

Thirdly, the two different words for "family" are used in the expression "the family of the Prophet". Thus whereas in the first half of the letter (III.1) and in the second speech (II.1), the word $\bar{a} l$ is used for "family," in the second half of the letter the word used is ahl. Although the words are used more or less synonymously in classical Arabic, I find it difficult to believe that the same author should have used the two different words in the same expression in a single text. 45

Each of these arguments for the second half of the letter being a later appendage would hardly have been enough in itself, but the cumulative evi-

42 I have not included the name of the group in this number.

43 See Hawting, "Tawwābūn," p. 171. See Pregill, "Turn in Repentance," p. 138 n. 75, for another 'unique' instance of this interpretation. Pregill's article is an excellent study of early interpretations of Qur'ān 2:54.

44 Al-Ṭabarī, Tärīh , ser. II, p. 501.

45 For the meanings of these words, see Lane, Arabic-English Lexicon, vol. 1, pp. 121, 127. 
dence in my opinion points to a process in which this is what has happened. It is difficult to say exactly where to draw the line between the original and the attached part. If, as I think, the original document as we have it is not the words of Sulaymān himself but, more likely, a rendering of the ideas of the Tawwābūn as they were remembered by people after them, the place and time for the meeting could have been part of the original; by the time of writing, the place and time of the meeting and the group's departure would have been generally known. Still, such concrete details strike a discordant note with the other texts, and it is perhaps more probable that it was part of the subsequently appended part. Be that as it may, my main hypothesis, to which I adhere in what follows, is that the second half of the letter (with or without the time and place for meeting) is a later attachment.

The final speech (Text IV) is also at variance with the first three texts. A couple of the elements listed from Texts I-III are missing. Thus the introduction does not mention the impending encounter with God after death. Also, the term " "šc $a$ " is not used anywhere in the text to designate the group. Furthermore, several elements not found in the previous texts are present in Text IV. The introduction brings up the merits of the Prophet Muhammad and the rights to authority of his descendants rather than the brevity of the present life. Similarly, the text ends with a promise to restore authority to the family of the Prophet. As in the texts examined above, al-Husayn is said to be the grandson of the Prophet, but in Text IV he is also described as the son of 'Alī, "the first of the Muslims in Islam". ${ }^{46}$ This is moreover the only time in these four texts that al-Husayn's name is spelt out. The structural differences between Texts IIII on the one hand and Text IV on the other are furthermore striking. Thus the content is arranged in a different manner. Whereas Texts I-III have more of a chronological disposition of the material, Text IV circulates around al-Husayn's position and character, and the wickedness of his adversaries. Although this is not the place for a full structural analysis of Text IV, it is clear that it is very well structured and that it features several literary and rhetorical figures. We have already seen that the theme of the authority of the descendants of the

$46 \quad$... ibn awwali l-muslimina isläman. Perhaps this phrase should rather be translated "the first of those who submitted among the submitters". The question of how one should translate the words muslim and isläm to a high degree depends on what position one takes in the question of when they began to be used as designations for a certain religious group and its adherents. For a date of this shift in use at the end of the first Muslim century (in other words, for the date I regard as the terminus ante quem for the origin of much of the story of the Tawwābūn), see Donner, Muhammad and the Believers. 
Prophet forms an inclusio which frames the speech. The text also contains other rhetorical devices, such as antithetical parallelisms and chiastic structures. ${ }^{47}$ The obvious conclusion of the arguments advanced above is that Text IV has an ultimate origin that differs from that of Texts I-III.

In the foregoing discussion I have already touched upon the content of the four programmatic texts, but in the following section I will develop this subject a little. In these four texts, three themes are prominent: the image of al-Husayn; the Karbala tragedy and the treachery of the Tawwābūn; and the dire consequences for the traitors and the need to repent.

The Image of al-Husayn

All texts emphasise that al-Husayn is the progeny of the Prophet. He is called "the son of our/their Prophet's daughter" (I..1; III.1; VI.2, 3). In one passage he is described as "the descendant of our Prophet, his offspring and his progeny, flesh of his flesh and blood of his blood (walad nabiyyina wa-sulälatuhu waușāratuhu wa-baḍ'atun min laḥmihiwa-damihi)" (II.2), and similar terms occur in other texts as well (I.4; IV.2). Thus all the texts trace his relationship with the Prophet through Fātima. In Text IV, however, his kinship to 'Alī is highlighted together with his blood relation to the Prophet through Fātima (IV.3). Texts III and IV furthermore dwell on his character; thus in section III.4 he is said to be "pure and good (al-zakiyyu al-tayyibu)," and in IV.3 he is described as "true and patient, trustworthy, helpful and resolute (... $\underline{\text { da }}$ șidq wa-șabr wa-dā amāna wanağda wa-ḥazm)".

The Karbala Tragedy and the Treachery of the Tawwābūn There is nothing like a full description of the events before and during the battle of Karbala. These things are only alluded to. One reason for this is that obviously everybody understands what is referred to. The event is so well known that it is unnecessary to relate it in these texts, and the emphasis is rather on the interpretation of what happened. Thus the events themselves are outlined only very briefly in Texts I-III:

(a) The first contacts between the Shiites of Kufa and al-Husayn (exchange of letters, invitation of al-Husayn);

(b) The coming of al-Ḥusayn;

47 Although similar techniques are found in the previous texts as well (e.g. the parallelism in the last sentence of II.2), they are not at all as frequent and prominent as in Text IV. 
(c) His plea for help and support from the Shiites and their failure to respond; and

(d) His attack and killing by the evil-doers.

In Text IV, only the treachery (c) and the killing (d) are mentioned.

If familiarity with the Karbala event is one reason why it was not necessary to relate it in full, another explanation might be that it had not yet been developed into a full story. There was probably no real consensus on what was to be included in it at this time, and it had not yet developed into a complete narrative in the sense that we have it in later versions (such as that ascribed to Imam al-Bāqir ${ }^{48}$ or that related by Abū Mihnnaf ${ }^{49}$ ). Several details found in the more developed versions that could easily have been included even in these brief references are lacking. So, for example, names of the major perpetrators could have been mentioned, and nothing is said about Muslim b. 'Aqil's mission, alHusayn's attempts to negotiate with the enemies, or even the name of the place where the battle occurred. ${ }^{50}$

The Dire Consequences for the Traitors, the Need to Repent, and the Manner of Repentance

This is perhaps the most conspicuous theme in these texts. It distinguishes the ideology of the Tawwābūn from that of other Shiites, and is found in all four texts (I.4, II.4-6; III.4-5; IV. 4-6). The Tawwābūn regard their betrayal of alHusayn as a mortal sin against God. This sin must be atoned for by avenging his death or dying in the attempt. If - as I will argue below - the parts of the story that I analyse here originate in the late first/early eighth century, the call for repentance or penitence, tawba, is indeed one of the earliest instances of this urge preserved for us in Islamic literature outside of the Qurān. It occurs frequently in early Sufism, but the literature that preserves deliberations over it is several decades later. ${ }^{51}$

The root $t-w-b$ and its derivatives can literally be translated "to turn". In the Qurān, this verb is used both with humans and with God as subjects: the two

48 Al-Ṭabarī, Tārīh, ser. II, pp. 227-232, 281-283.

49 Al-Ṭabarī, Tärīh , ser. II, pp. 232-281, 288-39o.

$5^{\circ} \quad$ Al-Taff (the plain on which Karbala was situated and often used as synonymous for the latter) is mentioned in a speech ascribed to Sulaymān b. Surad just before the battle at 'Ayn al-Warda (ibid., p. 556). For the name "al-Taff," see Kramers, "Al-Taff," $E I^{2}$, vol. 10, p. 82.

$5^{1} \quad$ For this concept in the Qur'ān, see Denny, "Qur’anic vocabulary of repentance”. For its use in early Sufism, see Böwering, "Early Sufism". 
are interdependent. ${ }^{52}$ Thus it says: "Whoever turns (in repentance) [man tāba] after his evildoing and sets (things) right—surely God will turn to him [ $f a$ inna llāhu yatūbu 'alayhi],"53 and "He [God] turned to them (in forgiveness) so that they might (also) turn (in repentance) [täba 'alayhim li-yatūbu]". ${ }^{54}$ In the story of the Tawwābun both these uses of the root $t-w-b$ appear, but with a heavy preponderance on the side of the human's repentance and turning to God; of the eighteen occurrences of the root that I have found, only two talk about God's turning or relenting towards humankind..$^{55}$ So the emphasis in the story is clearly on the need for the Shiites to repent of their sin of betraying al-Husayn. As the texts quoted above demonstrate, the Tawwābūn believe that the only way to show a sincere repentance for this offence is to be prepared to die. An important example of this idea is the unusual interpretation in Text II.5 of Qurān 2:54, discussed above. The full verse goes:

And when Moses said to his people, "My people! Surely you have done yourselves evil by taking the calf. So turn $[t \bar{u} b \bar{u}]$ to your Creator (in repentance), and kill yourselves. ${ }^{56}$ That will be better for you in the sight of the Creator." Then He turned to you (in forgiveness) [tāba]. Surely He- He is the One who turns (in forgiveness) [al-tawwāb], the compassionate.

Sulaymān quotes only the first part of the verse. Hawting argues that in the Tawwābūn's interpretation of this verse we find the link between the Jewish celebration of the Day of Atonement and the Shiite 'Āšūrā' festival. The common denominator, according to Hawting, is the yearning for atonement, something which the Tawwābūn thought could only be reached by sacrificing their lives in the attempt to exact revenge for the killing of al-Husayn.

By turning to God in repentance and sacrificing their own lives, the Tawwābūn hoped that God would likewise turn to them in forgiveness. Although this

$5^{2}$ Denny, "Qur'anic vocabulary of repentance," p. 655.

53 Qur'ān 5:39. I use the translation by Droge (Qur'ān). Throughout this article, transcriptions of Arabic phrases in square brackets are added by me.

54 Qửān 9:118.

55 Both these occurrences are both found in the third habar in the section of the visit to the grave. See below for a quote where they are included.

$5^{6}$ Droge has translated the words uqtulu anfusakum "kill one another". This is probably more in line with the original intention of the text in the Qurann. Here, I have followed Hawting's more literal translation (Ṭabarī, History, p. 83; Hawting, "Tawwābūn") as it seems to be the way these words were understood by the Tawwābūn. See also note 67 in Droge's translation. 
second meaning of the root $t-w-b$ is unusual in the story, the reciprocity is clearly implied throughout. The Tawwābūn hoped and prayed that God would forgive and "turn" to them if they sincerely repented. This is also understood by the citation from Qurān 2:54. As we have seen above, God's "turning" to the human in forgiveness comes in the second part of the verse-left out in the quote by Sulaymān — as a corollary to man's repentance. Although God's tawba towards the human being is only implied in Sulaymān's speech, that hope is expressed explicitly many times in the narrative of the story.

After the battle against the Umayyad army at 'Ayn al-Warda, where most of the Tawwābūn were killed, 'Abd Allāh b. Gaziyya, one of the survivors, said of those who had died in the battle: "May God have mercy on you! You have been true and borne your suffering patiently. We have been false and fled." ${ }^{57}$ Thus it seems that the survivors failed to secure God's forgiveness, the corollary of a true tawba.

\section{The Visit to the Grave}

The section that deals with the Tawwābūn's visit to al-Husayn's grave is central to the story in at least two ways. It is situated roughly in the middle of the text, and it narrates a symbolically very rich episode in their endeavour. ${ }^{58} \mathrm{I}$ have analysed this part of the story elsewhere in an attempt to date it. ${ }^{59}$ I must here repeat some of the arguments and conclusions from that previous study, but to save space I will keep the analysis as brief as possible and reproduce only short excerpts from the text, rather than quote it in full. For the complete text I refer to my previous study or to an edition of al-Tabarì's Tärīh.

The visit to the tomb of al-Husayn is the only part of the story which is related in more than one version: it is given in three versions, three $a h b \bar{a} r$; for the sake of analysis I have called them Habar I, II, and III. In the chain of authorities that commence the ahbār, two informants come between the event described and Abū Mihnaf in Habar I and II; three in Habar III. Two of the themes found in the four programmatic texts figure prominently in the section about the visit to the grave: the role and the image presented of al-Husayn, and the repentance of the Tawwābūn. The theme of the Karbala tragedy and the treachery of the Kufans, so important in those four texts, is much less conspicuous here,

$5^{8}$ This section is found in al-Tabarī, Tärīh, ser. II, pp. 546-548.

59 Hylén, "Date”. 
although it is clearly implied. I will discuss these three themes before finally discussing the ritual aspects that are visible in this section of the story.

\section{The Role and Image of al-Husayn}

In Habar II we read:

When we reached the tomb of al-Husayn (peace be upon him) the people wept together, and I heard most of the people expressing the wish that they had fallen with him. Sulaymān said: "Oh God, have mercy on al-Ḥusayn, the martyr [al-šahìd] son of the martyr, the right-guided one [al-mahdī] son of the right-guided one, the righteous one [al-șiddīq] son of the righteous one. Oh God, we call you to witness that we follow their religion $[\operatorname{din}]$ and their path, and we are enemies [ $\left.a^{c} d \bar{a}^{j}\right]$ of those who killed them, and friends [awliy $\left.\bar{a}^{3}\right]$ of those who love them."60

The epithets by which al-Ḥusayn is described here-šahìd, mahdī, and șiddìq - are of course not unusual in early Islam, and not particularly Shiite. Yet they indicate that the persons being so described are in a sense more than the ordinary Muslims who regarded them as leaders of the community. More interesting is the connection between al-Husayn and his father 'Alī. Not only are the two described in the same terms (al-šahìd ibn al-šahid, etc.), but the text also speaks of "their religion and their path" (innā 'alā dìnihim wa-sabïlihim). As Mohammad Ali Amir-Moezzi has shown, the early concept of the religion of 'Alī (dìn 'Alī) very strongly connotes profound affection (walāya) for 'Alī. ${ }^{61}$ Here father and son are juxtaposed, and the writer talks of their religion and their path. Furthermore, the concepts of affection or love (walāya) and enmity ('ad $\bar{a}$ ) so frequently used to distinguish those within the Shiite community from those outside it are used here to assert that the Tawwābūn belonged to the ranks of the true believers.

In Habar III, al-Husayn is called "the son of our Prophet's daughter". ${ }^{2}$ Here, then, al-Husayn's blood relationship with the Prophet Muhammad is emphasised over his connection with his father 'Alī. Further on in the same habar we read: "By God, I saw them thronging about his tomb more thickly than the people throng around the Black Stone." 63 This association between al-Husayn's grave and the Black Stone of the Kaba is quite remarkable. Dakake regards it as

\footnotetext{
6o Al-Ṭabarī, Tārīhn, ser. II, p. 546.

61 Amir-Moezzi, "Dìn 'Alī".

62 Al-Ṭabarī, Tārīhn, ser. II, p. 546.

63 Al-Ṭabarī, Tārīh, ser. II, p. 547 .
} 
a symbol for the "concept of the sanctity of al-Husayn as the bearer of Prophetic blood." ${ }^{4}$ Although Dakake may be over-stretching the interpretation of this statement, as we do not know exactly what symbolic significance was attached to the Black Stone at this time, it is clear that the association between the stone and al-Husayn is meant to show that he is a very special person with a close relationship with God.

Al-Husayn's connection to God is taken a step further in the last passage to which I want to draw attention. It is ascribed to 'Abd Allāh b. Wāl, one of the leaders of the group: "Verily, by God, I consider al-Husayn and his father and brother as the best of Muhammad's community [who will be] interceding before God (wasilatan inda lläh) on the Day of Resurrection." to Jean Calmard, this is the first time al-Husayn is invoked as an intermediary (wasila) between God and humanity, even if the word does not here have the meaning that it received in later Shiism. ${ }^{66}$ Again, al-Husayn is mentioned together with his father, and this time also with his brother al-Hasan.

However, the indications that al-Husayn is being elevated to a status over and above an ordinary being in the eyes of the Tawwābūn contrast with another feature in this section: the consistent prayer for God's forgiveness for al-Husayn and His mercy on him. We saw one example in the first quotation above: "Sulaymān said: 'Oh God, have mercy on (irham) al-Ḥusayn ...'” In the third habar we can read: "No man would pass on until he had come to the tomb of al-Husayn and stood [in prayer] over it, and asked for mercy on him and pardon for him," and further on we read how the Tawwābūn, as they left the site passed by the grave and "prayed for [al-Husayn] and asked for mercy on him". ${ }^{67}$ I will return to this interesting tension in the image of al-Ḥusayn below.

\section{The Karbala Story and the Treachery of the Tawwābün}

The Karbala drama is alluded to only a few times in this section. The first is when the Tawwābūn assert that they are the "enemies of those who killed them [al-Ḥusayn and his father 'Alī]".68 The second instance is when Sulaymān and his companions ask for mercy for "al-Husayn and his companions, the martyrs and the righteous ones." ${ }^{69}$ The third case is found a little further on, where

\footnotetext{
64 Dakake, Charismatic Community, p. 94.

65 Al-Ṭabarī, Tārīh, ser. II, p. 547.

66 Calmard, "Culte," pp. 68-69.

67 Al-Ṭabarī, Tārīh, ser. II, p. 547.

68 Al-Ṭabarī, Tārīh, ser. II, p. 546. 'Alī was of course not present at Karbala, but had been killed around two decades earlier.

69 Al-Ṭabarī, Tärīh, ser. II, p. 546.
} 
Sulaymān prays: "Praise be to God who, if He had wished, would have honoured us with martyrdom with al-Husayn."70 Finally, one of the leaders of the Tawwābūn, 'Abd Allāh b. Wāl, is reported as saying: "Do you not marvel at how this nation has been tried because of them ['Alī, al-Ḥasan, and al-Ḥusayn]? They killed two of them, and then satisfied their thirst for killing with the third."71 Thus in the section dealing with the visit to the grave, the killing of al-Husayn at Karbala is referred to only in passing, and twice in connection with the deaths of his closest relatives. No mention is made of the sequence of events leading up to the killing of al-Husayn, as we saw in the foregoing analysis of the four programmatic texts. Furthermore, the betrayal of the Shiites of Küfa is explicitly mentioned only once (see the quote below), and otherwise is alluded to only in their pleas to God for forgiveness.

\section{The Repentance of the Tawwābūn}

As an example of the third theme, the following lines from Habar III are appropriate. There, Sulaymān b. Șurad and his companions pray:

Oh Lord, we have betrayed the son of our Prophet's daughter! Pardon us for what we did in the past and turn $[t u b]$ towards us, for you are the turning one $[a l-t a w w a \bar{b} b]$ and the compassionate one. Have mercy on alHusayn and his companions, the martyrs and the righteous ones. We call you to witness, Oh Lord, that we are doing the same as what they were when they were killed. "If you do not pardon us and have mercy on us, then we are among those who are lost." ${ }^{72}$

Here we see that the treachery against al-Husayn is regarded as a severe sin against God: an offence that will bring perdition on those who committed it, if they are not forgiven. The Tawwābūn's plea to God for forgiveness is closely associated with a declaration that they are now doing what al-Husayn and his companions did at Karbala when they were killed. Later in the same habar

$70 \quad$ Al-Ṭabarī, Tārīh, ser. II, p. 547.

71 Al-Ṭabarī, Tārīh, ser. II, p. 547. I have given Fishbein's translation (Fishbein, "Life of alMukhtār," p. 155), as I think it more accurate than Hawting's. Square brackets are added by me. It is a bit unclear from the text exactly who has killed the three 'Alìds.

There is in fact one more allusion to the Karbala episode in the speech by al-Mutannā b. Muharriba at the end of the section of the visit to the grave (al-Tabarī, Tärīh, ser. II, pp. 547-548). For several reasons, I have concluded that this speech is a considerably later addition, however (see Hylén, "Date"). For that reason, I do not take it into account here. 
Sulaymān expresses the wish that they might be martyred "on his [al-Husayn's] account". ${ }^{73}$ This corresponds with the assertion in the previous quote from Habar II that they follow the religion of al-Husayn and his father, are enemies of their enemies, and love those who love them.

\section{Ritual Aspects}

The section dealing with the visit of the Tawwābūn to al-Husayn's grave is, furthermore, one of the earliest accounts of an emerging Shiite ritual. In order to set the Tawwābūn's visit to the grave in a more general context, I will briefly summarise the relevant parts of Leor Halevi's book about death rites in the emerging Islamic community, before analysing the text. ${ }^{74}$ Halevi argues that rituals regarding death and the dead body are crucial in the establishment and preservation of the identity of a religious community. ${ }^{75}$ Earlier, pre-Islamic rituals of washing the corpse, visiting graves, praying for God's mercy and forgiveness for the deceased, and other customs associated with death and burial, were gradually "Islamicised" during the second and early third/eighth and early ninth centuries in order to mark differentiations from other communities and strengthen the unity within the Islamic umma. ${ }^{76}$ One such marker where the process of Islamisation is clearly visible is that of epitaphs on tombstones.

On a tombstone containing one of the earliest inscriptions known from a Muslim context, we read:

In the name of God, the Merciful the Compassionate, this grave belongs to 'Abd al-Raḥmān ibn Ḩayr al-Ḥağrī.

Forgive him, O God, and make him enter [Paradise] by your mercy, and let us go with him.

Seek forgiveness for him whenever this inscription is read, and say "Amen!"

This inscription was written in Ğumādā II of the year 31 [January or February of the year $\left.65^{2} \mathrm{CE}\right]{ }^{77}$

73 Al-Ṭabarī, Tārīh, ser. II, p. 547.

74 Halevi, Muhammad's Grave. For the importance of visits to graves in later Shī'ism, see also Schöller, The Living and the Dead, pp. 29-33.

75 Halevi, Muhammad's Grave, pp. 1-5, 234-240, and passim.

76 Halevi, Muhammad's Grave, pp. 14-32. The term "pre-Islamic religious traditions" here does not necessarily mean the ğăhili tradition that was supplanted by Islam, but includes traditions that existed before the emergence of Islam and continued to exist beside it in (for example, Judaism, Christianity, and Zoroastrianism) and to certain extents also were taken over and integrated into Islam.

The translation is from Halevi, Muhammad's Grave, p. 14, and the discussion of the lack 
Leor Halevi asks to what extent this inscription can be called "Islamic," as the only unambiguous indication that the deceased belonged to the movement that later came to be known under the label "Islam" is the reference to the higrri calendar. Although there is no reason to doubt that this 'Abd alRahmān identified himself as "Muslim," or perhaps as "Believer" (mu'min) or "Emigrant" (muhäğir), the inscription itself can hardly be said to be "Islamic". Halevi demonstrates that over the first centuries of Islam, epitaphs increasingly came to include references to the Prophet Muhammad, quotations from the Qurān, formulaic confessions of faith, etc. In a similar manner, other burial customs such as the washing of the dead body, the procession and communal prayer at the burial, and the physical appearance of the grave were given specific "Islamic" characteristics. Consequently, on a tombstone at a woman's grave about four decades later there are more "Islamic" characteristics, such as the reference to the Muslims as a family (the ahl al-isläm), lament over the Prophet's death, and the šahāda (although in slightly different form than we are used to). Still, though, there is no quotation from the Quraan. These only emerge towards the middle of the second/eighth century. ${ }^{78}$

My point here is that many supposedly Islamic traditions associated with death and burial existed already among Christians, Jews, and Zoroastrians, as well as in the $\ddot{g}$ âhili religious traditions. To a certain extent, the Muslims continued these customs and rituals, but placed them in a new context, adapted them and, in certain cases, gave them new content. In the same process, some earlier traditions were completely prohibited, and yet others were added. (This is true not only of rituals surrounding death and burial, of course, but also other rituals such as prayer, pilgrimage, fasting, etc.).

The account of the Tawwābūn's visit to the grave of Husayn is another example of the process of "Islamisation", or perhaps rather a "Shiitisation" of preIslamic rituals. Part of what is described in this text- the visit to the grave and the pleas to God for forgiveness and mercy for al-Husayn - is a ritual that was familiar in the context. On the other hand, there are some elements that are less usual in this setting: firstly, the Tawwābūn's repentance and their prayers for forgiveness for themselves rather than just for al-Husayn; secondly, their claim to be following the path of al-Husayn, his father, and his brother towards death, as this is the only way to expiate their sin of betrayal; and finally, in consequence of this, their uses of the concepts walāya ("love" or "affection") for the family of

of Islamic characteristics on the following pages. For a slightly different translation of the same text, see Donner, Narratives, p. 85. The Arabic text is available in El-Hawary, "Most Ancient Islamic Monument," p. 322. 
the Prophet, as well as barāa ("dissociation") and 'adāwa ("enmity") for their enemies. All these components will later develop in Shiism as delimiters of the true community. Conspicuous by its absence, however, is wailing in the sense of expression of sorrow for the death of al-Husayn. The grief that is manifested by the Tawwābūn is rather that of having sinned gravely against God.

\section{The Date of the Story: Further Considerations}

In my previous study of the story of the Tawwābūn, I attempted to date the part dealing with the visit to the grave. That analysis convinced me that it dates back to the end of the first Muslim century/the beginning of eighth century CE at the latest. In the following section I will begin by summarising the arguments advanced in that study, before I deal with the much more difficult question of the date of the four programmatic texts. ${ }^{79}$

A close analysis of the structures and wordings of the three ahbār that make up the section dealing with the visit to the grave shows that they in their turn are based on two older anonymous reports about the event (Report A and B). Habar I and III contain elements from both reports; Habar II is based on only one of the reports. Additional material has been attached to Habar III. This insertion was probably added after Abū Mihnaf, as it contradicts important facts given elsewhere in the story (see fig. 1).

This analysis can be used to date the section on the visit to the grave. We do not know when Abū Mihnnaf compiled the Kitāb Sulaymān b. Surad wa-Ayn alWarda, but to be safe, let us presume that he did so towards the end of his life, that is, sometime between $13 \mathrm{O}$ and his death at $157 \mathrm{AH}$ (roughly between $75^{\circ}$ and $774 \mathrm{CE}$ ). Given the differing wordings and structures of the three $a h b \bar{a} r$, it is most unlikely that he could have made them up himself. It would have been extremely hard to forge traditions like these, and the three ahbār were almost certainly available to Abū Mihnaf when he wrote the text. ${ }^{80}$ Hence these $a h b \bar{a} r$ must have been compiled in the generation before him, if not earlier; and in that process, the two anonymous reports A and в were used. The reports most likely have their origin in the generation before that. Thus (and this is in accordance with the asānid) there are two generations between Abū Mihnnaf and the

79 For a more detailed argument, see Hylén, "Date".

8o This argument is developed and used by Harald Motzki in his works on the development of Islamic jurisprudence (see e.g. Motzki, "Muṣannaf"). See also Najam Haider's discussion and application of this method regarding the early development of Shiism, Origins, pp. 24-53 where the methodology is discussed. 
Ca $180 / 800$

Ca $130 / 750$

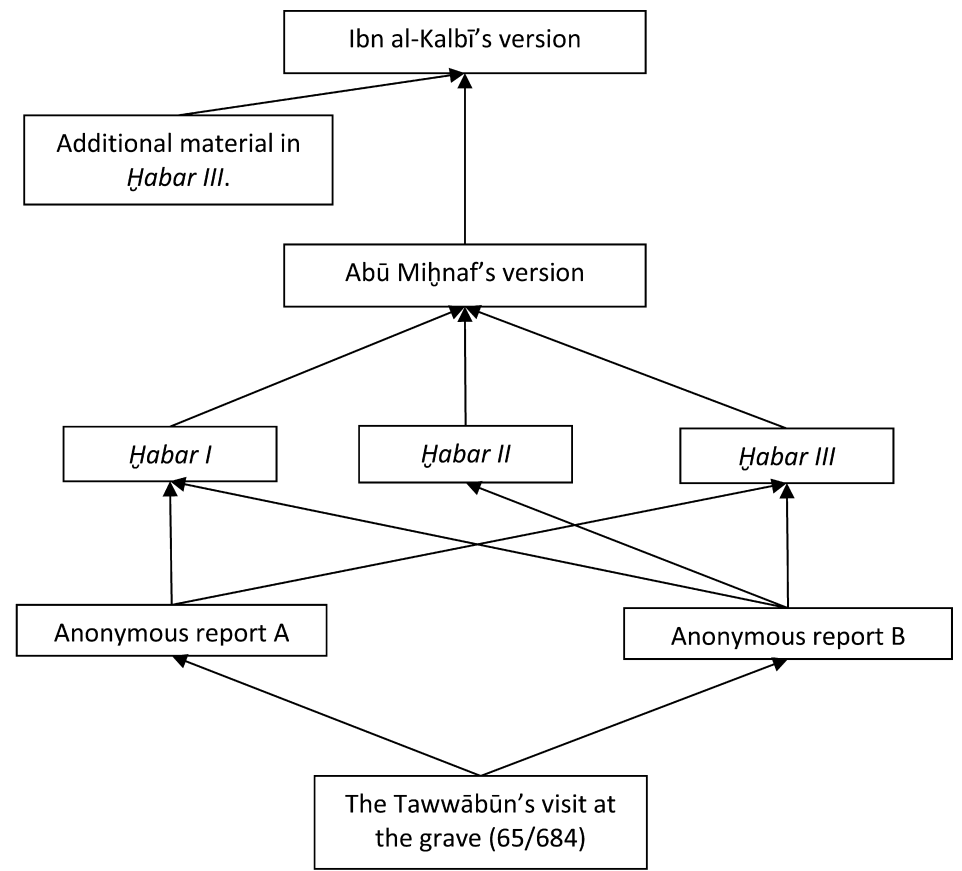

FIGURE 1 Tradition history of the account of the visit to Husayn's grave. The leftmost column indicates years.

two anonymous reports. This brings us back at least to the end of the first Muslim century/the beginning of the eighth century CE as the time of origin for these reports. Of course, they might very well have originated before that, and might even go back to eyewitnesses of the event. ${ }^{81}$ There is, however, no way in which we can know this for sure.

Unlike the section about the visit to the grave, then, the four programmatic texts are each extant only in one version. This makes it much more difficult to date them accurately. However, there are a few indications which in my view point towards a date as early as the visit to the grave.

Firstly, there is the curious interpretation of the Quranic verse relating the incident of the Hebrews and the Golden Calf, which I have already mentioned. Hawting writes:

81 Thus it is possible —although by no means certain — that the alleged narrator of Habar II, 'Abd al-Rahmmān b. Ġaziyya, who speaks in the first-person plural, actually was an eye witness, and that parts of Report B originate from him. Whether this is so or not we cannot know. I think, however, that some parts of this Habar are not original but have been added later. I will have more to say about this in a forthcoming study. 
That the Tawwābūn took Q. 2:54 as a guide to the way in which they should behave to atone for their own sin of having failed to help Husayn indicates a rather unusual position within Islam generally. ${ }^{82}$

Although Hawting does not state it explicitly, I assume he means that at the early date when the story — or at least parts of it — were composed, many tenets that were later considered to be truly Islamic had not yet developed. This argument, however, sets only a relative date in relation to the emerging movement of Islam: it is "early". In order to specify this general timing, it is useful to compare the programmatic texts with the section dealing with the visit to the grave. Such a comparison (which will be made below) suggests a similar date for both sets of text.

Secondly, I mentioned above that Text III - the letter purportedly written by Sulaymān b. Surad to the Shiites of al-Madāin and Basra-was reported to Abū Mihnnaf by al-Husuayn b. Yazīd, the grandson of 'Abd Allāh b. Sa'd b. Nufayl, one of the five leading figures of the Tawwābūn. Al-Husçayn b. Yazīd says that he read it when Sulaymān b. 'Abd al-Azīz was caliph (96-99/715-717). If this date is correct, it would give us a terminus ante quem for the origin of the letter. In my opinion, statements like this cannot be taken at face value unless supported by other evidence; the date could have been made up by the narrator to make his story seem more truthful, or he could have been mistaken. But in the present case the date provided is backed up (though certainly not completely verified) by the dating of the section dealing with al-Husayn's grave to the end of the first century AH/beginning of the eighth century CE. As I stated above, the similarities in structure and content between Texts I, II, and the first half of III argue for a similar origin for these texts (the second half of Text III, it will be remembered, I think is a later insertion).

Thirdly, the similarities between the ideas expressed in the four paradigmatic texts on the one hand and the visit to the grave on the other also argue for a similar date of origin. Unique to both sets of text is the intense feeling of guilt and the need to express true repentance through seeking vengeance for al-Husayn. These features are not present in the texts that, partly on other grounds, I have judged to be later additions to the story (in the programmatic texts, the second half of Text III, Sulaymān's letter; in the grave section, the speech by al-Mutannā b. Muharriba). Supposing these sections to be later insertions, the omission of the theme of guilt, which would have made them seem more authentic, could be accounted for either by later editors not sharing this 
feeling or by a conscious de-emphasis of it, whether for religious or other reasons. The expression of guilt is furthermore completely absent from the story of al-Muhtār b. Abī 'Ubayd, the leader of a Shiite rebellion in Kūfa just after the affair of the Tawwābūn. In other contexts I have argued that important elements of this story, including al-Muhtār's successful vengeance for the killing of al-Husayn, are probably historical. ${ }^{83}$ Whatever his motives for avenging alHusayn, there are no traces of guilt feelings in the different versions of the story about him. This feature, then, seems to have been quite unique to the Tawwābun. The fact that it is important both in the four programmatic texts and in the section dealing with the visit to the grave in my opinion indicates that these two sets of text are based on traditions with a similar date of origin.

Taken by itself, none of these three arguments is probative. But together they make a case for supposing that the programmatic texts originated in their present form at about the same time as the text narrating the visit to the grave, that is, in the late first/early eighth century. At least this goes for Texts I-III. As I have demonstrated above, Text Iv differs considerably from the first three, and it may be that it has a different origin in time.

\section{Conclusion}

In the analysis set out above of the Tawwābūn's visit to the grave, I suggested that a tension is visible between the image of al-Husayn as something more than an ordinary person and the prayer for God's mercy and forgiveness upon him. As we have seen, praying for God's mercy upon and forgiveness for the sins of a dead person was common. From the perspective of later developments in Shiite imamology, however, it is unexpected. In later Shiism, Ḥusayn is one of the fourteen mașummūn, those immune from error and sin or the "infallible," of the family of the Prophet. ${ }^{84} \mathrm{My}$ interpretation of the paradoxical behaviour ascribed to the Tawwābūn is that in this story we have an account of a movement in transition, where new ideas and practices are in the process of replacing old traditions, but the process is not yet complete. ${ }^{85}$ Here, the ritual aspect of the myth-making process is obvious. Both Gerald Hawting and Heinz Halm associate the story with the Shiite 'Āšunāà ritual that developed later. ${ }^{86}$ Of course

83 Hylén, Mukhtār and the Mahdī; idem, "Emerging Patterns".

84 For the concept of 'ișma, "inerrancy" or "impeccability," see e.g. Madelung, "Ișma," $E I^{2}$, vol. 4, pp. 182-184; Algar, “Čahārdah Ma'ṣūm," Encyclopaedia Iranica, vol. 5, pp. 627-629.

85 See also Hylén, "Date".

86 Hawting, "Tawwābūn”; Halm, Shi'a Islam, pp. 16-20. 
much of the sentiment and ethos of the later 'Āšurāa'-related rituals are found already here. In my opinion, though, the ritual that is really conspicuous in this text is the ziy $\bar{a} r a$, the pilgrimage to the graves of the Imams, which soon became so important to Shiites and which Najam Haider and Rose Aslan have demonstrated was a crucial aspect of the emergent Shiite identity. ${ }^{87}$

The myth-making process is visible also in the allusions to the events at Karbala, which are not set in a developed narrative matrix; in the story of the Tawwābūn, we find no story relating the death of al-Ḥusayn. The knowledge of the event is there, and references are made to it, but there is no full account of the tragedy. However, even if we had had a complete version of the Karbala story in the account of the Tawwābūn, this in itself would not be enough to determine whether it had functioned as a myth for the group in the sense defined above: a narrative that is foundational to a group's world view and identity. ${ }^{88}$ It is the attitude to al-Husayn and his relatives, the feeling of guilt not only towards the family of the Prophet but also towards God, the Tawwābūn's yearning for repentance and atonement, and the ritual of the visit to al-Husayn's grave described in the text, which signal that the whole complex of symbols surrounding the family of the Prophet is on its way to becoming something extraordinary, out of the usual; that a process of myth-making is under way. In the story of the Tawwābun we see how the narrative of a rather ordinary event-a minor skirmish at Karbala of the kind that occurred in many situations in the first decades of Islam ${ }^{89}$ — is on the way to becoming something extraordinary. In other words, we have here a prime example of the process by which the dialectic between story, practice, and attitude combine to build up the identity of a specific group in emerging Islam.

\section{Bibliography}

Amir-Moezzi, Mohammad Ali, "Reflections on the Expression din 'Ali: The Origins of the Shici Faith," The Study of Shic Islam: History, Theology and Law, ed. Farhad Daftary and Gurdofarid Miskinzoda, London: I.B. Tauris, 2014, pp. 17-46.

Asad, Talal, Genealogies of Religion: Discipline and Reasons of Power in Christianity and Islam, Baltimore: Johns Hopkins University Press, 1993.

87 Haider, Origins, pp. 243-248; Aslan, "From Body to Shrine".

88 Strictly speaking, we can of course never know what the Tawwābūn themselves thought about this. All we have is the ideas of the people who transmitted the story to us.

89 See e.g. Shaban, Islamic History, p. 91; Hawting, First Dynasty, pp. 50-51. 
Aslan, Rose. "From Body to Shrine: The Construction of Sacred Space at the Grave of 'Ali Ibn Abi Talib in Najaf," unpublished Ph.D. thesis, University of North Carolina, 2014.

al-Balādurī, Aḥmad b. Yaḥyā, Ansāb al-Ashrāf, vol. 5, ed. S.D. Goitein, Jerusalem: Hebrew University, 1936.

Bell, Catherine M., Ritual: Perspectives and Dimensions, Oxford: Oxford University Press, 1997.

Böwering, Gerhard, "Early Sufism between Persecution and Heresy," Islamic Mysticism Contested: Thirteen Centuries of Controversies and Polemics, ed. Frederick De Jong and Bernd Radtke, Leiden: Brill, 1999, pp. 45-67.

Calmard, Jean. "Le culte de l'Imām Ḥusayn: Etude sur la commémoration du Drame de Karbalā dans l' Iran pré-safavide," unpublished Ph.D. thesis, University of Paris, 1975.

Connerton, Paul, How Societies Remember, Cambridge: Cambridge University Press, 1989.

Conrad, Lawrence I. "Ibn A'tham and His History," Al- Ușūr al-Wusțā: The Journal of Middle East Medievalists 23 (2015), pp. 87-125.

Dakake, Maria Massi, The Charismatic Community: Shicite Identity in Early Islam, New York, NY: State University of New York Press, 2007.

Denny, Frederick Mathewson. "The Qur'anic vocabulary of repentance: orientations and attitudes," Journal of the American Academy of Religion Thematic Studies 47 (1979), pp. 649-664.

Donner, Fred M., Muhammad and the Believers at the Origins of Islam, Cambridge, MA: Belknap Press of Harvard University Press, 2010.

Donner, Fred M., Narratives of Islamic Origins: The Beginnings of Islamic Historical Writing, Princeton N.J.: Darwin, 1998.

Droge, Arthur J., The Qur'ān: A New Annotated Translation, Sheffield: Equinox, 2013.

Durkheim, Émile, Les Formes élémentaires de la vie religieuse, Paris: Librairie Félix Alcan, 1925 .

El-Hawary, Hassan Mohammed, "The Most Ancient Islamic Monument Known Dated A.H.31 (A.D. 652) from the time of the third Calif 'Uthman," Journal of the Royal Asiatic Society 62 (1930), pp. 321-333.

van Ess, Josef, Theologie und Gesellschaft im 2. und 3. Jahrhundert Hidschra: eine Geschichte des religiösen Denkens im frühen Islam, Berlin: de Gruyter, 1991-1997.

Fishbein, Michael, "The Life of al-Mukhtār b. Abī 'Ubayd in Some Early Arabic Historians," unpublished PhD Thesis, University of California, Los Angeles, 1988.

Gottschalk, Peter, Beyond Hindu and Muslim: Multiple Identity in Narratives from Village India, Oxford: Oxford University Press, 2000.

Gruenwald, Ithamar, Rituals and Ritual Theory in Ancient Israel, Leiden: Brill, 2003. Haider, Najam, The Origins of the Shĩa: Identity, Ritual, and Sacred Space in EighthCentury Küfa, Cambridge: Cambridge University Press, 2011. 
Halevi, Leor, Muhammad's Grave: Death Rites and the Making of Islam, New York: Columbia University Press, 2007.

Halm, Heinz, Shi'a Islam: From Religion to Revolution, Princeton: Marcus Wiener Publishers, 1997.

Hawting, Gerald R., The First Dynasty of Islam: The Umayyad Caliphate AD 661-750, London: Routledge, 2000.

Hawting, Gerald R.. "The Tawwābūn, Atonement and 'Āshūrā’," Jerusalem Studies in Arabic and Islam 17 (1994), pp. 166-181.

Houseman, Michael, "Relationality," Theorizing Rituals: Issues, Topics, Approaches, Concepts, ed. Jens Kreinath, Jan Snoek and Michael Stausberg, Leiden: Brill, 2006, pp. $413-428$.

Humphrey, Caroline, and James Laidlaw, The Archetypal Actions of Ritual: A Theory of Ritual Illustrated by the Jain Rite of Worship, Oxford: Oxford University Press, 1994.

Hylén, Torsten. "The Date of the Story of the Tawwābūn," Studia Islamica 112 (2017) pp. $175^{-205}$.

Hylén, Torsten. "Emerging Patterns of Authority in Early Shī'ism: al-Mukhtār's Use of the Aesthetics of Persuasion," [Forthcoming].

Hylén, Torsten. "Husayn, the Mediator: A Structural Analysis of the Karbala Drama according to Abū Jaffar Muhammad b. Jarīr al-Ṭabarī(d. 310/923)," unpublished Ph.D. thesis, Uppsala University, 2007.

Hylén, Torsten. "Mukhtār and the Mahdī: A Critical Inquiry into the Sources," DIN: Tidsskrift for religion og kultur, (2018 [Forthcoming])

Ibn A'țam al-Kūfî, Ahmad, Kitāb al-Futūḥ, 8 vols., ed. Muḥammad 'Abd al-Mu'īd Huān et al., Haydarabad: Matbaat Majlis Dairat al-Maarif al-Uthmaniyah, 1972.

Ibn al-Nadīm, Muḥammad ibn Ishāā, Kitāb al-Fihrist, 2 vols., ed. Gustav Flügel, Johannes Roediger and August Müller, Leipzig: Vogel, 1871-1872.

Jafri, Syed Husain Mohammad, The Origins and Early Development of Shi'a Islam, Oxford: Oxford University Press, 1979.

Kohlberg, Etan. "From Imāmiyya to Ithnā-'Ashariyya," Bulletin of the School of Oriental and African Studies 39 (1976), pp. 521-534.

Kohlberg, Etan. "Imām and Community in the Pre-Ghayba Period," Authority and Political Culture in Shi ism, ed. Said Amir Arjomand, Albany, N.Y.: State University of New York Press, 1988, pp. 25-53.

Lane, Edward W., Arabic-English Lexicon, 2 vols., Cambridge: Islamic Texts Society, 1984 (1863-1893).

Leder, Stefan, "The Literary Use of the Khabar: A Basic Form of Historical Writing," The Byzantine and Islamic Near East. Vol. I, Problems in the Literary Source Material, ed. A. Cameron and L. Conrad, pp. 277-315, Princeton, N.J.: Darwin, 1992.

Lincoln, Bruce, Theorizing Myth: Narrative, Ideology and Scholarship, Chicago: University of Chicago Press, 1999. 
Lindstedt, Ilkka, "Al-Madāinī's Kitāb al-Dawla and the Death of Ibrāhīm al-Imām," Case Studies in Transmission, ed. Ilkka Lindstedt et al., Münster: Ugarit-Verlag, 2014, pp. $103-130$.

Lindstedt, Ilkka, "Sources for the Biography of the Historian Ibn A'tham al-Kūf̂," Orientalia Lovaniensia Analecta 254 (2017), pp. 299-309.

Mack, Burton L., Who Wrote the New Testament?: The Making of the Christian Myth, San Francisco, CA: HarperSan Francisco, 1995.

al-Mas'ūdī, Abū al-Ḥasan, Kitāb Murūğ al-Dahab (Les Prairies d'Or), 9 vols., ed. C. Barbier de Meynard, A., Parvet de Courteille, Paris, 1861-1877.

McCutcheon, Russel T., "Myth," Guide to the Study of Religion, ed. Willi Braun and Russel T. McCutcheon, London: Cassell, 200o, pp. 190-208.

Meier, John P., A Marginal Jew:Rethinking the HistoricalJesus. Vol. 4, Law and Love, New Haven, CT: Yale University Press, 2009.

Motzki, Harald. "The Muṣannaf of 'Abd al-Razzāq al-San'ānī as a Source of Authentic A hạdìth of the First Century A.H.," Journal of Near Eastern Studies 50 (1991), pp. 1-21. Noth, Albrecht, and Lawrence I. Conrad, The Early Arabic Historical Tradition: A SourceCritical Study, Princeton, N.J.: Darwin, 1994.

Penn, Michael Philip, Kissing Christians: Ritual and Community in the Late Ancient Church, Philadelphia, PA: University of Pennsylvania Press, 2005.

Pregill, Michael E. “'Turn in Repentance to your Creator, then Slay Yourselves': The Levitical Election, Atonement, and Secession in Early and Classical Islamic Exegesis," Comparative Islamic Studies 6 (2010), pp. 101-150.

Schoeler, Gregor, The Oral and the Written in Early Islam, London: Routledge, 2006.

Schöller, Marco, The Living and the Dead in Islam: Studies in Arabic Epitaphs. vol. 2, Epitaphs in Context, Wiesbaden: Harrassowitz, 2004.

Sezgin, Ursula, Abū Mihnaf: Ein Beitrag zur Historiographie der umaiyadischen Zeit, Leiden: Brill, 1971.

Shaban, M.A., Islamic History: A New Interpretation. Vol. 1. A.D.6oo-75o (A.H.132), Cambridge: Cambridge University Press, 1971.

al-Ṭabarī, Muhammad b. Jarīr, Tārīḩal-rusulwa-l-mulūk, 15 vols., ed. M.J. de Goeje et al., Leiden: Brill, 1879-1901.

al-Ṭabarī, Muhammad b. Jarīr, The History of al-Tabarī. Vol. xx: The Collapse of Sufyānid Authority and the Coming of the Marwānids, transl. Gerald R. Hawting, Albany, NY: State University of New York Press, 1989.

Turner, Victor W., The Ritual Process: Structure and Anti-Structure, Ithaca, N.Y.: Cornell University Press, 1977.

Wellhausen, Julius, Die religiös-politischen Oppositionsparteien im alten Islam, Berlin: Weidmannsche Buchhandlung, 1901. 